\title{
DISCHARGE FOR GRIPING AS AN UNFAIR LABOR PRACTICE*
}

A LEADING purpose of both the Wagner and Taft-Hartley Acts is the protection of employees from discharge for union activities. ${ }^{2}$ The statutory provisions implementing this aim are phrased in broad terms. Section S(a) (1) of the amended Wagner Act makes it an unfair labor practice to "interfere with" employee attempts at self-organization." Section $8(a)(3)$ forbids employer "discrimination" in hiring and firing which discourages union

*NLRB v. Office Towel Supply Co., 201 F.2d $\$ 38$ (2d Cir. 1953).

1. National Labor Relations Act, 49 Stat. 449 (1935), 29 U.S.C. $\$ 151$ et seq. (1946) (Wagner Act) [hereinafter cited as NLRA], as amended by the Labor Mianagement Relations Act of 1947, 61 STAT. 136 (1947), 29 U.S.C. $\$ 141$ et seq. (Supp. 1952) (TaftHartley Act) [hereinafter cited as LMRA].

The purposes of the NLRA and LAIRA were set forth in the following declaration of policy:

"It is hereby declared to be the policy of the United States to climinate the causes of certain substantial obstructions to the free flow of commerce and to mitigate and eliminate these obstructions when they have occurred by encouraging the practice and procedure of collective bargaining and by protecting the exercise by workers of full freedom of association, self-organization, and designation of representatives of their own choosing, for the purpose of negotiating the terms and conditions of their employment or other mutual aid or protection." NLRA $\$ 1$, 49 STAT. 449 (1935), 29 U.S.C. $\$ 151$ (1946); LMRA § 1, 61 STAT. 136-7 (1947), 29 U.S.C. \$ 151 (Supp. 1952).

2. "Sec. $S(a)$. It shall be an unfair labor practice for an employer-

(1) To interfere with, restrain, or coerce employees in the exercise of the rights guaranteed in section 7. . ." LMIRA, 61 STAT. 140 (1947), 29 U.S.C. $\$ 158(a)$ (1) (Supp. 1952).

And $\$ 7$ provides: "Employees shall have the right to self-organization, to form, join or assist labor organizations, to bargain collectively through representatives of their own choosing, and to engage in other concerted activities for the purpose of collective bargaining or other mutual aid or protection, and shall also have the right to refrain from any or all of such activities. . ." LAIRA, 61 ST.AT. 140 (1947), 29 U.S.C. $\$ 157$ (Supp. 1952). Except for the insertion of a clause in $\$ 7$ guaranteeing the right to refrain irom concerted activities, these provisions are identical to those in the NLRA, 49 SrAT. 452 (1935), 29 U.S.C. $\$ \S 15 \&(1), 157$ (1946).

The "concerted activities" protected by $\$ 7$ include not only traditional union activities but also any activity by two or more employees which is for the purpose of mutual benefit rather than for a purely personal reason. Sec NLRB v. Peter C. K. Swiss Checolates, 130 F.2d 503, 505-6 (2d Cir. 1942) ; Joanna Cotton Mills Co. v. NLRB, 176 F.2d 749, 752-3 (4th $\mathrm{Cir}$. 1949). Activities held to be protected under $\$ 7$ include passing a resolution of support for a farmers' union, NLRB v. Peter C. K. Swiss Chocolates, suspra; circulating a petition for overtime work, NLRB v. Schwartz, 146 F.2d 773 (5th Cir. 1945); protesting the employment of a cashier whose employment the employees think vill affect their earnings, NLRB v. Phoenix Mutual Life Ins. Co., 167 F.2d 983 (7th Cir. 1948); and marching through the aisles of the plant in protest against the discharge of a steward, NLRB v. J. I. Case Co., 198 F.2d 919 (8th Cir. 1952). See Note, 53 CuL L. Rev. 514 (1953). 
membership. ${ }^{3}$ An employer who discharges in violation of these provisions must reinstate the fired employee and compensate him for his loss of pay. But an employee can always be discharged, in the absence of a collective bargaining agreement which provides otherwise, for a good reason, ${ }^{5}$ or no reason at all. ${ }^{8}$ The fact that a worker is engaged in concerted activity ${ }^{7}$ does not protect him from discharge for a reason apart from that activity. ${ }^{8}$ However, an employer violates both $8(a)(1)$ and $8(a)(3)$ when he fires a worker because of the latter's legitimate union activities. ${ }^{0}$

3. "Sec. 8(a). It shall be an unfair labor practice for an employer-

...

(3) By discrimination in regard to hire or tenure of employment or any term or condition of employment to encourage or discourage membership in any labor organization. . ." LMRA, 61 Stat. 140 (1947), 29 U.S.C. $\$ 158$ (a) (3) (Supp. 1952). This provision is identical to that contained in the NLRA, 49 STAT. 452 (1935), 29 U.S.C. \& 158(3) (1946).

4. The NLRB shall require any person found to have committed an unfair labor practice "to take such affirmative action, including reinstatement with or without back pay, as will effectuate the policies of this Act." LMRA § 10(c), 61 STAr. 147 (1947), 29 U.S.C. $\S 160$ (c) (Supp. 1952). From the earliest cases the Board has held that the proper remedy for unlawful discharge is reinstatement and back pay from the date of discharge less sums earned elsewhere in the interim. E.g., Pennsylvania Greyhound Lines, Inc., 1 N.L.R.B. 1, 36 (1935). See also 16 NLRB ANN. REP. 242 (1951) and note 43 infra. For a discussion of the back pay provision, see Note, 62 YALE L.J. 488 (1953).

5. LMRA $\S 10(c)$ provides: "No order of the Board shall require the reinstatement of any individual as an employee . . . if such individual was suspended or discharged for cause." There was no such provision in the NLRA. Conppare LMRA \& 10(c), 61 STAT. 147 (1947), 29 U.S.C. $\$ 160$ (c) (Supp. 1952), with NLRA $\$ 10$ (c), 49 STAT. 454 (1935), 29 U.S.C. $\S 160$ (c) (1946). However under the NLRA courts always allowed discharge for cause. See, e.g., Martel Mills Corp. v. NLRB, 114 F.2d 624, 632 (4th Cir. 1940) (discharge for inefficiency and disobedience); NLRB v. Union Pacific Stages, 99 F.2d 153, 168 (9th Cir. 1938) (discharge for violation of company rules).

But where the cause of the discharge is found to be union activity, the discharge is illegal despite the fact that the employee was also guilty of conduct which would have justified discharge. E.g., Edward G. Budd Mfg. Co. v. NLRB, 138 F.2d 86 (3d Cir. 1943). See also NLRB v. Blue-Bell Globe Mfg. Co., 120 F.2d 974, 975 (4th Cir. 1941).

6. E.g., Cusano v. NLRB, 190 F.2d 898, 902 (3d Cir. 1951); Edward G. Budd Mfg. Co. v. NLRB, 138 F.2d 86 (3d Cir. 1943) ; NLRB v. Tex-O-Kan Flour Mills Co., 122 F.2d 433 (5th Cir. 1941).

For a discussion of how collective bargaining contracts may restrict employer freedom to discharge, see Comment, 62 Yale L.J. 954, 972 (1953).

7. See note 2 supra.

8. See, e.g., NLRB v. Ray Smith Transport Co., 193 F.2d 142, 146 (5th Cir. 1951) (union member discharged for discourtesy to customer) ; NLRB v. West Ohio Gas Co., 172 F.2d 685, 688 (6th Cir. 1949) (active unionist discharged for inefficiency).

9. See, e.g., NLRB v. Weyerhaeuser Timber Co., 132 F.2d 234, 236 (9th Cir. 1942). The Board generally holds a discharge in violation of $\S 8(\mathrm{a})(1)$ to be a discriminatory discharge and thus violative of $\S 8($ a) (3). E.g., Gullett Gin Co., 83 N.L.R.B. 1, 2 (1949). Since the remedy of reinstatement and back pay is the same whether one or both sections are violated, the distinction between $\S 8(\mathrm{a})(1)$ and $\S 8(\mathrm{a})(3)$ is rarely considered. Westinghouse Electric Corp., 77 N.L.R.B. 1058, 1061 (1948). Sec 14 NLRB ANN. REp. 61 (1949). Occasionally the courts have held that although a discharge was based on an 
In NLRB v. Office Towel Supply Co. ${ }^{10}$ the Second Circuit decided that a discharge for griping does not violate Sections $S(a)(1)$ and $S(a)(3)$ where the employer had no knowledge that the griping was part of an attempt to organize a union. During a recess period discussion concerning working conditions and the need for a union, employee Jenifer commented, "This is a hell of a place to work. They expect one girl to do the work of five and a girl doesn't get time to go to the ladies' room."11 The office manager learned of the remark and reported it to the company's president, who fired Jenifer primarily beeause of her grousing. ${ }^{12}$ The National Labor Relations Board determined that the president was not aware that Jenifer had been discussing the need for a union in the plant. ${ }^{13}$ The Board also held that the discussion was concerted activity within the meaning of Section 7 of the amended Wagner Act and that since Jenifer was fired for conduct which was part of this activity, the discharge was unlawful regardless of the employer's lack of knowledge. ${ }^{14}$ But the Second

employee's engaging in a protected activity, only $\$ \$(a)(1)$ was violated since no discrimination tending to discourage membership in a labor organization was shown. NLRB v. J. I. Case Co., 198 F.2d 919 (Sth Cir. 1952) (employees discharged for organizing protest march in plant); Gullett Gin Co. v. NLRB, 179 F.2d 499 (5th Cir. 1950) (cmployees discharged for questioning employer about wages). For discussion of the Case decision, see Note, Back Pay Auards for Linfair Lahor Practices under the Taft-Hartley Act, 62 Y ALE L.J. 4S\$, 494 (1953). For discussion of the $\$ \$(a)(1)-\$ \$(3)$ (3) dichutomy, see Note, 53 CoL. L. REv. 514, 524 (1953).

The protection of $\$ S(a)$ (1) does not extend to concerted activities conducted for a purpose which is unlawful or contrary to the policies of the Act. NLRB v. Fansteel Corp., 306 U.S. 240 (1939) (sitdown strike) ; NLRB v. Draper Corp., 145 F.2d 199 (4th Cir. 1944) (wildcat strike). See 16 NLRB Aws. Rep. 170-3 (1951).

10. 201 F.2d 838 (2d Cir. 1953), denying cuforcenent to 97 N.L.R.B. 449 (1951).

11. Id. at 839 .

12. The president conceded that Jenifer's remark was "the crux of the whole thing." Id. at 839 n.1. Neither the Board nor the court opinion makes clear how the oftice manager learned of Jenifer's remark. 97 N.L.R.B. 449, 451, 459 (1951) ; 201 F.2d 838, 839 (2d Cir. 1953).

13. 97 NLRB 449, 450-1 (1951). There was no specific finding that the office manager was unaware of the context of the remark, but since the Board did not discuss "imputation of knowledge," the manager's ignorance of the context seems lik:ely. Sce note 24 infra.

14. "The Trial Examiner's dismissal of the discharge ... indicates a failure to consider the applicability of settled law that once it is made to appear from primary facts that an employer has violated the express provisions of the Act, then his motives are not relevant. In this posture, the crucial issue is whether the conduct for which Jenifer was discharged was protected by the Act." 97 N.L.R.B. 449, 450 (1951). The Board went on to find that the discussion in which Jenifer participated was a protected activity. Id. at 451. The Board seems to have confused knowledge and motive. The "motive" cases, NLRB v. Gluek Brewing Co., 144 F.2d 847 (Sth Cir. 1944), and NLRB v. Hudson Motor Car Co., 128 F.2d 528 (6th Cir. 1942), involved jurisdictional disputes in which employers were forced by circumstances to favor one union over another. This intentional favoritism was held to be illegal even though moticated solely by desire to avoid disruption of the employer's business. These cases are not analogous to the situation where the employer is ignorant of the facts which make his action interference with protected activities. 
Circuit reversed the NLRB's determination that the employer's imperfect knowledge was irrelevant. Judge Frank, for the majority, held that griping, apart from the context of concerted activity, is not protected by the Act and that since the employer knew only of the griping, Jenifer was not fired "because" of her unionizing activity. ${ }^{15}$ Judge Clark sharply dissented on the ground that the majority was gratuitously reading into the Act a "knowledge" requirement which "will have a paralyzing trend on attempts at unionization."10

The question whether Sections 8(a)(1) and 8(a)(3) prohibit a discharge for conduct which, unknown to the employer, is a part of concerted activity has several times been considered by the courts. ${ }^{17}$ The Sixth Circuit in 1949 upheld the discharge of an employee who had complained to other workers that wage rates at another plant were higher. ${ }^{18}$ Though the worker was in fact discussing wages in an attempt to organize a union, the court, in a per curiam opinion, denied enforcement to the NLRB's back pay order on the ground that the management neither knew nor had a duty to ascertain the nature of the employee's activity. ${ }^{10}$ However, since the employee in that case was apparently discharged for disrupting production by agitating on the job, ${ }^{20}$ his discharge might have been lawful even if the employer had known of the concerted nature of his activity. ${ }^{21}$ Nor is the Office Towel case compelling authority for the

15. NLRB v. Office Towel Supply Co., 201 F.2d 838, 840 (2d Cir. 1953).

16. See id. at $842-3$ (dissenting opinion).

17. An earlier NLRB case apparently incorporated a "knowledge" requirement. Myers Products Corp., 84 N.L.R.B. 32 (1949). There the Board held that an employee was lawfully discharged for demanding a raise when the employer did not know that he was speaking for a group of men. There were, however, also elements of insubordination in the employee's conduct. Judge Clark, dissenting in the Office Tozvel case, termed the Myers decision "no formal ruling of law ... but an ad hoc decision on the facts which the Board should make." 201 F.2d 838, 842 n.2 (1953). See also note 18 infra and accompanying text.

One court, on a somewhat unique fact situation, indicated employer knowledgc was not necessary for finding a violation of $\S \S 8(a)(1)$ and $8(a)(3)$. Home Beneficial Lifo Ins. Co. v. NLRB, 159 F.2d 280 (4th Cir.), cert. denied, 332 U.S. 758 (1947) (insurance company without knowledge that employees were on strike discharged them on mistaken belief they were violating working rule). Similarly in other contexts the employer's knowledge has been held immaterial in determining a violation. Cusano v. NLRB, 190 F.2d 898 (3d Cir. 1951) (mistaken belief that employee had lied about company profits); Ohio Associated Telephone Co., 91 N.L.R.B. 932 (1950) (mistaken belief as to misconduct by striker).

18. NLRB v. Westinghouse Electric Corp. 179 F.2d 507 (6th Cir. 1949) denying enforcement to 77 N.L.R.B. 1058 (1948).

19. Id. at 508 .

20. Westinghouse Electric Corp., 77 N.L.R.B. 1058, 1069 (1948) ; NLRB v. Westinghouse Electric Corp., 179 F.2d 507, 508 (6th Cir. 1949).

21. See, e.g., Wyman-Gordon Co. v. NLRB, 153 F.2d 480, 487-9 (7th Cir. 1946) (discharge valid because employee slowed up production by discussing union on job); Alabama Fuel \& Iron Co., 62 N.L.R.B. 762, 771-2 (1945) (discharge for union soliciting on job valid). But cf. Ames Spot Welder Co., 75 N.L.R.B. 352, 354-5 (1947) (discharge unlawful where motivated by desire to stop organizing activities). 
"knowledge" requirement. Judge Frank seemed to have some doubt that Jenifer was in fact engaged in a protected concerted activity at the time of her discharge, ${ }^{22}$ and although he did not overrule the Board on this point, the doubt may have influenced the decision. Certainly a court unwilling to adopt the "knowledge" requirement could distinguish both the Second and Sixth Circuit decisions.

Even if Office Towel's requirement of employer awareness is followed, it will not hinder "open" organizational attempts. Since many campaigns are accompanied by sound trucks, handbills, and union buttons, 23 the employer will in all likelihood realize that what might in other circumstances appear to be idle griping is actually organizational activity. If supervisory workers know of the organizational movement, the Board will usually infer that the employer lnew also. ${ }^{24}$ And although the employer can claim he did not lnow that a particular worker discharged for grousing was engaged in an organizational attempt, the Board, in determining the real cause of the discharge, may weigh such factors as the employer's knowledge of the existence of the campaign, ${ }^{20}$ the employer's previous attitude toward unionism, ${ }^{20}$ and the punishment meted out in the past for griping. ${ }^{27}$

But where organization is just getting underway, the knowledge requirement may seriously impair the campaign's effectiveness. Secrecy if often essential at least in the initial stages of an organizing effort." ${ }^{-3}$ This is particularly true in small plants where the presence of the "boss" is acutely felt and the fear of his displeasure is real. ${ }^{29}$ Secrecy may also be necessary in predominantly nonunion areas, where community coercion may be exerted against union leaders and where the workers themselves may be distrustful of unions. ${ }^{30}$ And whether

22. Judge Frank cites with approval Board Chairman Herzog's dissenting statement at 97 N.L.R.B. 454, that Jenifer's remarks did not constitute "the sort of concerted activity which Congress intended this Board to protect." NLRB v. Office Towel Supply Co., 201 F.2d 838, 840 (2d Cir. 1953). For a similar interyretation, see Xote, 53 Cor. L. REV. 514, 525 (1953).

23. See, e.g., Republic Aviation Corp., 51 N.L.R.B. 1186 (1943); Ford Motor Co., 14 N.L.R.B. 346 (1939).

24. See, e.g., Stokely Foods, Inc., 91 N.L.R.B. 1267, 1269 (1950); Ozark Hardwood Co., 91 N.L.R.B. 1443, 1445 (1950).

25. See, e.g., NLRB v. El Paso-Ysleta Bus Line, 190 F.2d 201, 262 (5th Cir. 1951); Bogue Electric Co., 60 N.I.R.B. 935, 942 (1945).

26. See, e.g., NLRB v. Electric City Dyeing Co., 178 F.2d 980, 982 (3a Cir. 1950); National Die Casting Co., 94 N.L.R.B. 845, 847 (1951).

27. See, e.g., NLRB v. State Center Warehouse Co., 193 F.2d 156, 158 (9th Cir. 1951); NLRB v. Ford, 170 F.2d 735, 738-9 (6th Cir. 1948).

28. See, e.g., Bell Bakeries Inc, 97 N.L.R.B. 1423, 1426-7 (1952); Westinghouse Electric Corp., 77 N.L.R.B. 1058, 1067-8 (1948). Also see ILGIVU, Hasidedes of Tranz UNTON METHODS 10 (1948).

29. See, e.g., Bell Bakeries Inc., 97 N.L.R.B. 1423, 1420-7 (1952) ; Ames Spot Welder Co., 75 N.L.R.B. 352, 361-8 (1947). Also see note 33 infru.

30. On the problems involved in organizing non-union territory, see ILGWU, HAzDbook of Trade Union Mfethods 5-12 (1948); Brooks, When Lagos Ogarizes 1-15. 
the organizer acts openly or secretly, his most effective weapon is personal conversation with the other workers about grievances. 31 The "linowledge" rule creates a dilemma for those who are attempting to organize a union. If the say nothing to the employer about their intentions, they risk discharge for any overheard remarks critical of the management. ${ }^{32}$ But if the organizers give notice to the employer that they are attempting to form a union, the alerted employer will be able to fight organization of his plant when the union movement is weakest and most vulnerable to employer coercion. ${ }^{33}$

While the Office Towel rule may hamper incipient union activity, forbidding discharge of gripers who are engaged in organizational activity seemingly works a hardship on employers. Management, in attempting to investigate a worker's union background before discharge, may run afoul of the Board's rule against interrogation of employees. ${ }^{34}$ But if the griper is fired without

(1937). For examples of community pressure against union movements, see NLRB v. American Furnace Co., 158 F.2d 376, 379 (7th Cir. 1946) ; Blue Ridge Shirt Mfg. Co., 70 N.L.R.B. 741, 751-7 (1946).

31. The most effective organizational work is done through personal contact with the workers at their homes and inside the plant. Interview with Mr. Edward McCrone, Regional Director, Connecticut C.I.O. The organizer's discussion with the other cmployees emphasizes grievances and then moves on to the subject of how a union could improve the situation. ILGWU, HANDBOOK of TRADE UNION METHods 9-10 (1948).

32. See text at note 14 supra.

Since an outside organizer can rarely gain access to the plant, the organizational work inside the plant must be carried on exclusively by the employees. Interview, note 31 supra.

33. The employer's only legal means of resisting organization lies in expressing counterarguments to his employees. The employer right of free speech is guaranteed by § 8(c) of the LMRA, 61 STAT. 142 (1947), 29 U.S.C. \$ 158(c) (Supp. 1952). However, this weapon may be a potent one, especially if the employer's means of communication with the employees is more effective than that of the union. See Bonwit Teller, Inc. v. NLRB, 197 F.2d 640 (2d Cir. 1952), 61 YaLE L.J. 1066. Furthermore, employer resort to illegal anti-union activity is not rare, as the volume of unfair labor practice litigation attests. The NLRB handles approximately 4,000 employer unfair labor practice cases a year. 14 NLRB ANN. REP. 164 (1949); 15 NLRB ANN. REl. 226 (1950); 16 NLRB ANN. REP. 299 (1951). Ninety percent of these cases are settled before formal action is taken. It is reasonable to assume that many violations never reach the NLRB, because workers are apathetic or ignorant of their rights.

Occasionally, an employer may find it to his advantage to forestall unionization of his plant by discharging the leaders of the union movement even though he will ultimately be forced to reinstate them with back pay. Interview, note 31 supra. See also note 43 infra.

Judge Clark, dissenting in Office Towel, stated that the decision would paralyze attempts at unionization. "These [union movements] can no longer grow and be nurtured from tender shoots to bloom; they must spring up full blown or hardiy at all." $201 \mathrm{~F} .2 \mathrm{~d}$ 838, 843 (2d Cir. 1953).

34. Standard-Coosa-Thatcher Co., 85 N.L.R.B. 1358, 1360-2 (1949); Notc, 62 YALE L.J. 1258 (1953). But the Board has held that when an employer, acting in response to a union allegation that an employee was discharged for engaging in a concerted activity, makes an investigation into the circumstances of the discharge, the employer's 
investigation, the employer, under the Board's rule, will have to reinstate him and grant back pay if the grumbler was in fact organizing. ${ }^{35}$ Thus management's right to fire malcontents will be limited when the context is not readily ascertainable. However, that the employer needs protection against ordinary griping seems doubtful : occasional grumbles do not pose a real threat to plant discipline. ${ }^{38}$ And the chronic complainer is likely to prove insulordinate or inefficient and can be legitimately discharged on those grounds. ${ }^{3 T}$ Balanced against the discouraging effect on unionizing which Office Ton'd threatens, the burden of requiring management to reinstate workers fired for organizational griping appears slight. 38

The position that employer knowledge is not an essential element of an unfair labor practice seems consistent with the demands of Section $S(a)(1)$, if not with those of $8(a)(3) .^{39}$ It is difficult to see how an employer can "discriminate" under $8(a)$ (3) unless he knows of the union affiliation of the candidate for discharge, but the courts have generally tested "interference" under $8(a)(1)$ in terms of tendency and effect rather than of motive or intent. ${ }^{40}$ Thus a company rule against solicitation, designed only to prevent

action is proper provided that the investigation is limited to the relevant issues. Mray Department Stores Co., 70 N.L.R.B. 94 (1946). Perhaps the same principle would apply to an investigation to determine whether an employee should be discharged.

35. See text at note 14 stipra.

36. Suppression of griping may be more dangerous than allowing workers to "let off steam." "Management can afford to give its employees the right to be heard or to 'sound off' without fear of reprimand ... It is also better to let the employce express his irritation instead of letting it smolder and become an aggravated grievance." PErssu:NEL HANDBOoK 923 (Miee ed. 1951). For a discussion of the "clinical" approach to discipline and other personnel problems, see Priffner, Tue Suresuision of Personsab 275-375 (1951).

37. Discontent is likely to lead to lowered production and a loss of interest in the work. See, e.g., Parker \& Kiegareier, Hrasax Rel.itions in Supervision 3:0-8 (1951). While discharge is not the ideal solution in such cases, see Prifrases, op. cit. sufra note 36 , at $327-44$, the employer is clearly within his legal rights in taking such action.

38. "[T] he National Labor Relations Board [must work] cut an adjustment between the undisputed right of self-organization assured to employees under the Wagner . Aet and the equally undisputed right of employers to maintain discipline in thsir establishments. Like so many others, these rights are not unlimited in the sense that they can be exercised without regard to any duty which the existence of rights in others may place upon employer or employee... [The Wagner Act] left to the Board the work of applying the Act's general prohibitory language in the light of the infinite combinations of events which might be charged as violative of its terms." Reed, J., in Republic Aviation Corp. v. NLRB, 324 U.S. 793, 797-S (1945).

39. See notes 2,3 , and 9 supra.

40. "The test is whether the employer engaged in conduct which, it may reasonably be said, tends to interfere with the free exercise of employee rights under the Act." NLRB v. Illinois Tool Works, 153 F.2d 811, S14 (7th Cir. 1940). See NLRE v. Ford, 170 F.2d 735, 738 (6th Cir. 1948).

Section $8(a)(1)$ is the broadest provision defining employer uniair labor practices, and the Board has considered any violation of the other four provisions of Section $8(a)$ to be a violation also of $8(a)$ (1). Furthermore, conduct not covered by the other pro- 
peddling or littering, may violate 8 (a) (1) when applied to union organizers : : $^{11}$ the "no-solicitation" rule is illegal regardless of its innocent purpose becausc it curtails self-organization at "the very time and place uniquely appropriate and almost solely available." 42 A discharge for griping which is in fact part of an organizational attempt in effect sets up a "no-solicitation" rule during the initial and most crucial phase of unionization, because it discourages other employees from engaging in similar conduct. Such a discharge should not be upheld, regardless of the employer's state of knowledge: section 8 (a) (1)'s purpose is not to punish guilty employers but to encourage employee organization. ${ }^{43}$

visions may be violative of $8(a)$ (1), e.g., no-soliciting rules, interrogation, and surveillance of union activities. 14 NLRB ANN. REP. 50-1 (1949). A discharge may violate 8 (a) (1) although it does not violate 8(a)(3). See note 9 supra.

The Board in the Office Towel case had found the discharge to be violative of both 8(a) (1) and 8(a) (3), and the Second Circuit in reversing the decision did not analyzc the sections separately.

41. Rules restricting solicitation of union memberships on company property during non-working hours are presumed invalid under $\$ 8(a)(1)$ in the absence of special circumstances. Republic Aviation Co. v. NLRB, 324 U.S. 793 (1945) ; NLRB v. Illinois Tool Works, 153 F.2d 811 (7th Cir. 1946) ; I. F. Sales Co., 82 N.L.R.B. 137, 138 (1949) (paid luncheon and rest periods not "company time"). An employer may prevent the distribution of literature in the plant proper in the interest of cleanliness where there is no showing that distribution cannot be conducted elsewhere. Monolith Portland Cement Co., 94 N.L.R.B. 1358, 1365-6 (1951) (ban on distribution upheld); Carolina Mills, Inc., 92 N.L.R.B. 1141, 1166 (1951) (ban illegal because distribution off premises would be ineffective). See 16 NLRB Ann. Rep. 147 (1951); Labor Relations and tue LAW 585-6 (Mathews ed. 1953).

For detailed review of no-solicitation rules, see Daykin, Employes' Right to Orangize on Company Tine and Property, 41 ILL. L. REv. 301 (1947); Note, 61 YALE L.J. 1066 (1952).

42. Republic Aviation Corp., 51 N.L.R.B. 1186, 1195 (1943), quoted in Republic Aviation Corp. v. NLRB, 324 U.S. 793, 801 n.6 (1945).

43. The purpose of the remedies of reinstatement and back pay is not punitive but compensatory. Thus the employer is liable only for the employee's net loss in wages. Social Security Board v. Nierotko, 327 U.S. 358, 364-5 (1946). See also NLRB v. Nelson Mfg. Co., 120 F.2d 444, 446 (8th Cir. 1941). And the employee must mitigate the loss by seeking other employment. Phelps Dodge Corp. v. NLRB, 313 U.S. 177, 197-8 (1941): Harvest Queen Mill \& Elevator Co., 90 N.L.R.B. 320, $321-2$ (1950); Ohio Public Service Co., 52 N.L.R.B. 725, 729 (1943). 